\title{
Clinical profile, drug resistance pattern and treatment outcomes of abdominal tuberculosis patients in Western India
}

\author{
Suhas UDGIRKAR, Samit JAIN, Sunil PAWAR, Sanjay CHANDNANI, Qais CONTRACTOR and Pravin RATHI
}

Received 12/3/2019 Accepted 28/4/2019

\begin{abstract}
Background - Abdominal tuberculosis is an increasing problem in developing world. Objective - The objective of the study was to describe the clinical presentations, drug resistance pattern and treatment outcomes of abdominal tuberculosis in Western India. Methods - All the cases of abdominal tuberculosis from May 2014 to April 2017, diagnosed on the basis of clinical profile and gross morphological findings at endoscopy, imaging, followed by histology and/or GeneXpert and MGIT culture were included. All patients received antitubercular drug (AKT) therapy according to national protocol. Patients were followed from diagnoses till completion of treatment and various parameters were studied. Results - Out of the 176 patients, $48 \%$ were males. Abdominal pain was most common complaint in $83.5 \%$. On colonoscopy terminal ileum and ileocaecal valve were most commonly involved segments. Upper gastrointestinal tract was involved in four patients. Overall ulceronodular lesions were most common followed by ulcerative/nodular lesion. Strictures in bowel were seen in $28(15.9 \%)$ patients with ileocaecal valve being most commonly involved, of which 23 had symptomatic relief with AKT and only three required dilatation. Histopathology showed granuloma in $80.8 \%$ cases. MGIT was positive in 43 $(35.80 \%)$ cases and GeneXpert was positive in $35(26.1 \%)$ cases. Eight patients had multi drug resistant tuberculosis. Only two patients required surgical management. Conclusion - Abdominal tuberculosis with wide spectrum of presentation, can still be managed with early diagnosis and treatment even in patients with sub acute intestinal obstruction. Weight gain or resolving symptoms were considered early markers of treatment response. Patients with stricture can become asymptomatic with medical treatment alone.
\end{abstract}

HEADINGS - Tuberculosis. Drug resistance. Pathologic constriction. Granuloma.

\section{INTRODUCTION}

Tuberculosis (TB) causes about 3 million deaths per year worldwide and its incidence is on the rise in both developed and developing countries ${ }^{(1)}$. Poverty, deprivation, overcrowding, illiteracy, and limited access to health care facilities are some of the factors for the increasing menace of tuberculosis in developing countries. However, in the developed countries, tuberculosis is more commonly accompanied with HIV infection, ageing population or due to trans-global migration ${ }^{(2,3)}$. Approximately one eighth of TB cases are extra pulmonary and of these abdominal tuberculosis (ATB) accounts for $11 \%-16 \%{ }^{(4,5)}$. In HIV positive patients the incidence of extra pulmonary TB is up to $50 \% \%^{(6,7)}$. From $6 \%$ to $38 \%$ of patients with intra-abdominal TB have evidence of pulmonary TB at the time of diagnosis ${ }^{(8)}$. Primary abdominal TB is due to the reactivation of a dormant focus acquired in the past. Secondary disease occurs when infection spreads to the abdomen via swallowed sputum, hematogenous spread or from an infected neighboring organ or ingestion of unpasteurized milk ${ }^{(3,6)}$. In India, the organism isolated from all intestinal lesions has been Mycobacterium tuberculosis and not $M$. bovis ${ }^{(9)}$. Intestinal (enteric) tuberculosis exists in three main forms: ulcerative, hypertrophic or ulcero hypertrophic, and fibrous stricturing form $^{(10,11)}$. Peritoneal involvement (TB peritonitis) exists in four main forms: ascitic, loculated (encysted), plastic (fibrous) and purulent forms ${ }^{(10)}$. Lymph nodes in the small bowel mesentery and the retroperitoneum are commonly involved, and these may caseate and calcify. Disseminated abdominal tuberculosis involving the gastrointestinal tract, peritoneum, lymph nodes and solid viscera has also been described ${ }^{(11)}$. Presentation varies from an asymptomatic state to a surgical emergency. Diagnosing abdominal tuberculosis is a diagnostic challenge due to its varied presentation and difficulty in accessing tissue. The disease can mimic various gastrointestinal disorders, particularly inflammatory bowel disease (IBD), colonic malignancy, or other gastrointestinal infections. Intestinal tuberculosis can present with abdominal pain, constipation and vomiting suggestive of intestinal obstruction. Recurrent attacks of sub-acute intestinal obstruction can occur. Localized or generalized ascites and abdominal distension, diarrhea, fever, weight loss, melena and anemia could be seen ${ }^{(12)}$. Despite advances in imaging, early diagnosis of abdominal tuberculosis is not easy and patients often present with advanced disease. The treatment of abdominal tuberculosis is mainly nonsurgical with anti-tuberculous drugs and surgery is reserved for complications such as intestinal obstruction and bowel perforation with peritonitis ${ }^{(12)}$.

With the help of new molecular methods, drugs based on culture can be given. Though literature on drug resistance is sparse, our study gives evidence for drug resistance in abdominal TB and need for routine tissue culture sensitivity. 
We have attempted to describe the clinical presentation, natural history and treatment outcomes of abdominal tuberculosis in western India. We have also analyzed factors predicting response to treatment and how abdominal TB patients here differ from other parts of India and the world.

\section{METHODS}

\section{Study design and patient selection}

This was a hospital based descriptive study where prospectively maintained database of patients attending luminal gastroenterology clinic of a tertiary care referral center in Western India from May 2014 to April 2017 was analyzed.

All the cases of abdominal tuberculosis diagnosed on the basis of clinical profile and supported by gross morphological findings at endoscopy, and/or diagnostic laparoscopy (when needed), followed by histology and/or GeneXpert and MGIT culture were included.

Following investigations were done in every case: complete blood count, liver function tests (LFT), renal function tests (RFT), ESR, Manotoux test, chest X-ray, X-ray erect abdomen, ultrasound (USG) abdomen and computed tomography (CT) of abdomen. All patients with bowel wall thickening more than $3 \mathrm{~mm}$ on ultrasound or CT abdomen underwent upper gastrointestinal (GI) or lower GI endoscopy and four to six biopsies from suspicious lesions taken for MGIT (Mycobacterial Growth Indicator Tubes (MGIT) system (BACTEC MGIT 960 TB; Becton Dickinson Biosciences, Sparks, MD, USA) were used for mycobacterial culture, GeneXpert (Cepheid Inc., Sunnyvale, CA, USA) and histopathology. Histology was reported by a single expert.

Patients with enlarged abdominal lymph nodes on imaging underwent USG guided lymph node fine needle aspiration cytology (FNAC) or biopsy when feasible and samples were sent for the above mentioned studies. Diagnostic paracentesis was done in cases with ascites and was tested for complete and differential cell count, total protein, albumin, glucose and adenosine deaminase (ADA). Resistance pattern for first line drugs and second line drugs was done in patients with positive GeneXpert and positive MGIT culture.

\section{Treatment protocol}

Patients with histologically proven granuloma or positive GeneXpert or MGIT were started on anti--tubercular therapy (ATT) as per Revised National Tuberculosis Control Programme (RNTCP) according to resistance patterns. Patients with a high clinical suspicion of TB but negative histopathology, GeneXpert and culture were started on empirical ATT for a period of eight weeks. The drugs were discontinued subsequently if they did not have any clinical improvement. Patients with drug susceptible TB were treated with four agents (Rifamipcin, Ethambutol, Isoniazid and pyrazinamide) and response to treatment was evaluated every two months ${ }^{(13)}$ Patients with multi drug resistant (MDR) tuberculosis were given treatment for 18 months in which 6 to 9 months of Kanamycin (Kn), Levofloxacin (Lfx), Ethionamide (Eto), Cycloserine (Cs), Pyrazinamide (Z), Ethambutol (E), Isoniazid (H), and Lfx, Eto, Cs, E, H in the continuation phase for 18 months.

\section{Follow up}

Patients were followed at monthly interval in the intensive phase and then two monthly till the completion of treatment. After completion of treatment they were followed up if they had recurrence of symptoms. As per our protocol liver biochemistry were repeated every two weeks in intensive phase and subsequently if they had any symptoms suggestive of ATT induced hepatitis. Repeat colonoscopy was done in patients: 1) in whom empirical ATT was given after two months of starting treatment to document any objective improvement, 2) in patients with colonic stricture at the end of the treatment to evaluate for the persistence of stricture, and 3 ) in patients not responding to first line ATT, to evaluate for MDR tuberculosis.

\section{Study variables}

The study variables included socio-demographic characteristics (i.e. age and sex, level of education, occupation and area of residence), clinical presentation, HIV coinfection, radiological findings, endoscopic findings, Mantoux, ESR, MGIT, GeneXpert and response rate to antitubercular drugs.

\section{Statistical analysis}

Continuous variables were expressed as mean \pm SD. Categorical variables were expressed as percentages

\section{RESULTS}

TABLE 1 shows the demographic and clinical characteristics of patients with abdominal tuberculosis.

Out of the 176 patients, $84(48 \%)$ were males. Most of the patients $(94.88 \%)$ were from age group 11 to 60 years-youngest being 8 years and oldest being 70 years. Majority of the patients were from slums belonging to the lower socioeconomic class. Abdominal tuberculosis was more common in students, labourers and housewives.

Average duration of symptoms was $165+/-23$ days.

Abdominal pain, weight loss and anorexia were commonly reported. Fever was the next common complaint which was low grade, intermittent with only few patients reporting the characteristic evening rise. Few patients had abdominal distension, vomiting, bleeding per rectum and diarrhea mimicking IBD as their initial presentation.

Only $7(3.9 \%)$ patients had recent family history of tuberculosis. Concomitant pulmonary TB was present in $13(7.3 \%)$ and $12(6.8 \%)$ had a past history of TB (mostly pulmonary).

Of the five patients with features of intestinal obstruction two required exploratory laparatomy and the other three were managed conservatively. Only one patient had laparoscopy for diagnosis.

On radiological evaluation (TABLE 2) terminal ileum and ileocaecal (IC) valve were the most commonly affected segment followed by caecum, ascending colon, transverse colon, sigmoid colon and rectum (FIGURE 1A). Abdominal CT was more useful in detecting thickening and stricture than USG.

Endoscopic features are depicted in TABLE 3. Colonoscopy was done in 162 patients. Terminal ileum and IC junction were most commonly involved. After IC junction, the most common sites of involvement were caecum, ascending colon, transverse colon, descending colon, sigmoid colon and rectum respectively (FIGURE 1B). Twenty-nine (16.4\%) patients had stricture on colonoscopy with IC valve being the commonest site. However, only eight of these caused significant narrowing resulting in inability to pass the colonoscope. On subsequent colonoscopy at the end of treatment complete stricture resolution was seen in only three $(10.34 \%)$, partial resolution in $18(62.06 \%)$ and persistent stricture 
TABLE 1 . Demographic and clinical parameters.

\begin{tabular}{|c|c|}
\hline & $\mathbf{N}(\%)$ or mean $\pm \mathrm{SD}$ \\
\hline Total & $176(100)$ \\
\hline Male & $84(48)$ \\
\hline Female & $92(52)$ \\
\hline \multicolumn{2}{|l|}{ Age(yrs) } \\
\hline$<10$ & $2(1.14)$ \\
\hline $11-20$ & $35(19.89)$ \\
\hline $21-40$ & $82(46.59)$ \\
\hline $41-60$ & $50(28.41)$ \\
\hline $61-70$ & $7(3.97)$ \\
\hline \multicolumn{2}{|l|}{ Residence } \\
\hline Chawl /Slum /Flat & $103(58.52) / 55(31.25) / 18(10.23)$ \\
\hline \multicolumn{2}{|l|}{ Profession } \\
\hline Student & $51(28.98)$ \\
\hline Housewife & $43(24.43)$ \\
\hline Laborer & $16(9.09)$ \\
\hline Others & $66(37.50)$ \\
\hline Duration of symptoms (mean) & $165+/-23$ days \\
\hline \multicolumn{2}{|l|}{ Clinical presentations } \\
\hline Abdominal pain & $147(83.52)$ \\
\hline Fever & $104(59.09)$ \\
\hline Weight loss & $141(80.11)$ \\
\hline Anorexia & $152(86.36)$ \\
\hline Bleeding per rectum & $13(7.39)$ \\
\hline Diarrhea & $10(5.68)$ \\
\hline Abdominal distention & $44(25)$ \\
\hline Vomiting & $13(7.38)$ \\
\hline Intestinal obstruction & $5(2.8)$ \\
\hline \multicolumn{2}{|l|}{ Examination findings } \\
\hline Pallor & $94(53.40)$ \\
\hline Lymph nodes` & $6(3.4)$ \\
\hline Clubbing & $2(1.14)$ \\
\hline Hepatomegaly & $13(7.39)$ \\
\hline Splenomegaly & $3(1.7)$ \\
\hline Ascites & $23(13.14)$ \\
\hline Lump & $5(2.84)$ \\
\hline \multicolumn{2}{|l|}{ Biochemical parameters } \\
\hline $\mathrm{Hb}(\mathrm{g} / \mathrm{dL})$ & $8.3+/-2.1$ \\
\hline ESR (mm at one hour) & $56+/-34$ \\
\hline Baseline SGOT & $23+/-12$ \\
\hline Baseline SGPT (IU/mL) & $18+/-7$ \\
\hline Mantoux test $(>10 \mathrm{~mm})$ & 113 \\
\hline Pulmonary involvement (n) & 13 \\
\hline Ascitic fluid ADA (iu/mL) & $36+/-10$ \\
\hline
\end{tabular}

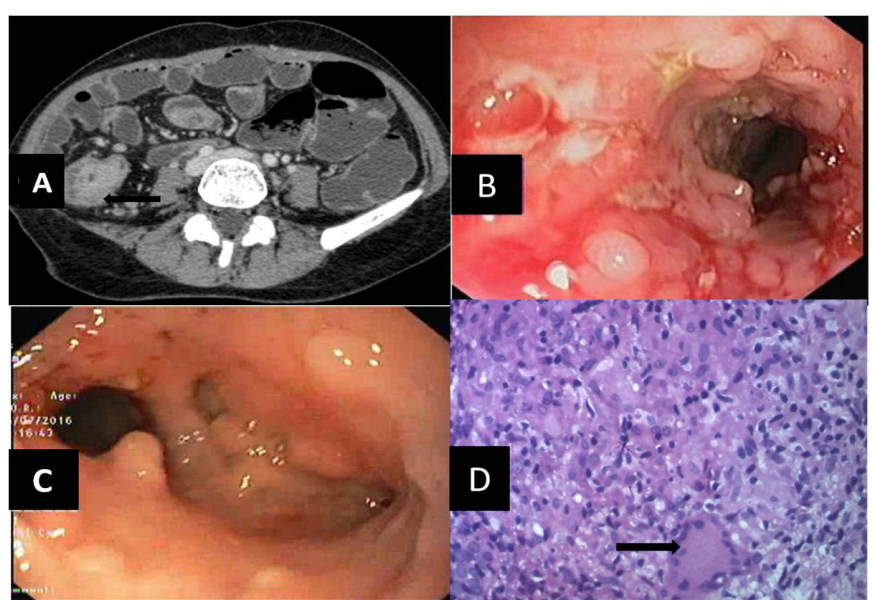

FIGURE 1. A) CT enterography showing enhancing thickening (arrow) of IC junction area typical of tuberculosis. B) Lower GI endoscopy showing ulceronodular lesions in transverse colon colon. C) Upper GI endoscopy with gastroduodenal nodularity with fistulous opening. D) Histopathological section (haematoxylin and eosin stain $100 \mathrm{X}$ ) showing ill formed Langerhans giant cells (arrow) with granuloma formation.

in $7(24.13 \%)$. One patient with intestinal obstruction died. However, symptomatic improvement was seen in $24(82.75 \%)$ of these patients after nine months of ATT and no further intervention was necessary. Endoscopic balloon dilatation was effective in three patients and one patient required surgical intervention for persistent stricture. Four patients had associated upper gastrointestinal involvement - one had esophageal and gastric non-healing ulcers with fistulous opening near pylorus. Two other patients had gastric outlet obstruction due to ulceronodular lesion in the duodenum which did not require surgery (FIGURE 1C). One patient had ulcer proliferative growth at cardia of the stomach. All four patients had well formed granulomas on histology and responded completely to antitubercular therapy.

Molecular methods like MGIT and GeneXpert were positive in 43/120 (35.8\%) and 35/136 (25.73\%) patients respectively. Four patients had both tests positive.

Two patients had mono resistance, eight patients had MDR tuberculosis and none had XDR tuberculosis. Sensitivity, specificity, positive predictive value and negative predictive value of MGIT and GeneXpert are shown in TABLE 4. Histologically confirmed granuloma was seen in $131(80.83 \%)$ patients on colonoscopic biopsy specimens and on abdominal lymph node FNAC in five patients with predominance of epitheloid macrophage and langerhans giant cells (FIGURE 1D).

All patients with ascites had negative ascitic fluid MGIT and GeneXpert. Patients with no other evidence of tuberculosis except for high protein and low SAAG ascites (n-4) were given empirical anti-tubercular drugs.

TABLE 2. Abdominal imaging in tuberculosis.

\begin{tabular}{|c|c|c|c|c|c|c|c|}
\hline Imaging & $\begin{array}{c}\text { Terminal Ileum+ IC } \\
\text { valve } \mathbf{N}(\%)\end{array}$ & $\begin{array}{l}\text { Caecum } \\
\mathbf{N}(\%)\end{array}$ & $\begin{array}{l}\text { Ascending } \\
\text { colon N (\%) }\end{array}$ & $\begin{array}{c}\text { Transverse } \\
\text { colon N }(\%)\end{array}$ & $\begin{array}{l}\text { Descending } \\
\text { colon N }(\%)\end{array}$ & $\begin{array}{l}\text { Sigmoid } \\
\mathbf{N}(\%)\end{array}$ & $\begin{array}{l}\text { Rectum } \\
\mathbf{N}(\%)\end{array}$ \\
\hline USG (positive findings) & $70(39.77)$ & $57(31.25)$ & $23(13.06)$ & $10(5.6)$ & $2(1.1)$ & $2(1.1)$ & $1(0.5)$ \\
\hline Stricture & 12 & 10 & 3 & 3 & 0 & 1 & 0 \\
\hline
\end{tabular}

IC: ileocaecal; USG: ultrasonography; CT: computerized tomography. 
TABLE 3. Endoscopic findings in abdominal tuberculosis.

\begin{tabular}{lc}
\hline Upper GI endoscopy & N $(\%)$ \\
Upper GI endoscopy & 10 \\
Ulcer & 4 \\
Ulceronodular & 3 \\
Fistulous tract & 2 \\
Mass & 1 \\
Esophageal ulceration & 1
\end{tabular}

Colonoscopy

\begin{tabular}{|c|c|c|c|}
\hline & & No. & $\%$ \\
\hline & Nodular & 7 & $4.0 \%$ \\
\hline & Normal & 81 & $46.3 \%$ \\
\hline & Not studied & 10 & $5.7 \%$ \\
\hline Terminal ileum & Stricture & 6 & $1.1 \%$ \\
\hline & Ulcer & 36 & $22.85 \%$ \\
\hline & Ulceronodular & 22 & $12.57 \%$ \\
\hline & Deformed & 11 & $6.2 \%$ \\
\hline & Normal & 92 & $52.57 \%$ \\
\hline & Not studied & 5 & $2.8 \%$ \\
\hline Ileocaecal valve & Patulous & 6 & $1.1 \%$ \\
\hline & Stricture & 13 & $7.4 \%$ \\
\hline & Ulcer & 15 & $11.9 \%$ \\
\hline & Ulceronodular & 20 & $10.85 \%$ \\
\hline & Distorted & 8 & $1.3 \%$ \\
\hline & Nodular & 3 & $1.9 \%$ \\
\hline Cecum & Normal & 101 & $66.0 \%$ \\
\hline Cecum & Not studied & 5 & $3.1 \%$ \\
\hline & Ulcer & 21 & $11.3 \%$ \\
\hline & Ulceronodular & 24 & $15.1 \%$ \\
\hline & Normal & 134 & $82.4 \%$ \\
\hline & Not studied & 2 & $1.3 \%$ \\
\hline Ascending colon & Stricture & 4 & $2.5 \%$ \\
\hline & Ulcer & 8 & $5.0 \%$ \\
\hline & Ulceronodular & 14 & $8.8 \%$ \\
\hline & Normal & 147 & $91.2 \%$ \\
\hline & Not studied & 1 & $0.6 \%$ \\
\hline Hepatic flexure & Stricture & 2 & $0.6 \%$ \\
\hline & Ulcer & 3 & $1.9 \%$ \\
\hline & Ulceronodular & 9 & $5.7 \%$ \\
\hline & Normal & 151 & $94.3 \%$ \\
\hline Trancyerce colon & Stricture & 3 & $0.6 \%$ \\
\hline Iransverse colon & Ulcer & 3 & $1.9 \%$ \\
\hline & Ulceronodular & 5 & $3.1 \%$ \\
\hline & Normal & 157 & $96.9 \%$ \\
\hline Descending colon & Stricture & 1 & $0.6 \%$ \\
\hline Descending colon & Ulcer & 1 & $0.6 \%$ \\
\hline & Ulceronodular & 3 & $1.9 \%$ \\
\hline & Normal & 160 & $98.7 \%$ \\
\hline Sigmoid colon & Ulcer & 1 & $0.6 \%$ \\
\hline & Ulceronodular & 1 & $0.6 \%$ \\
\hline & Normal & 161 & $99.4 \%$ \\
\hline Rectum & Ulceronodular & 1 & $0.6 \%$ \\
\hline & Total & 162 & $100.0 \%$ \\
\hline
\end{tabular}

TABLE 4. Sensitivity, specificity, positive predictive value and negative predictive value of MGIT and GeneXpert (in percentages).

\begin{tabular}{lccccc}
\hline & Sensitivity & Specificity & PPV & NPV & Accuracy \\
\hline MGIT & 28.26 & 78.75 & 80.00 & 20.00 & 38.07 \\
GeneXpert & 25.36 & 89.47 & 89.74 & 24.82 & 39.20
\end{tabular}

All patients received ATT for at least six months. Twelve patients received category II and eight received category IV therapy. Three patients died due to TB meningitis and one patient due to intestinal obstruction. All the other patients recovered completely. One patient had drug induced rash and was managed with gradual increase in doses of ATT. One had drug induced hepatitis which was managed with hepatosafe ATT with streptomycin, levofloxacin and ethambutol for two month and was rechallanged successfully serially after normalization of liver function tests.

\section{DISCUSSION}

The exact incidence and prevalence of abdominal tuberculosis in India is difficult to establish as we lack a national registry for this disease.

Female predominance was one characteristic feature of abdominal tuberculosis in several studies in the past. In our current series $52 \%$ of the patients were females. Apart from malnutrition, illiteracy and poor access to health care facilities, contiguous spread from tuberculous salpingitis could be a possible reason $^{(14,15)}$. Most of these patients were from lower socioeconomic group and majority of them were middle aged i.e. reproductive age group ${ }^{(10,16,17)}$. Median duration from symptoms to detection of disease was 90 days but varied from 15 days to 2 years. Most common presenting complaint abdominal pain, was similar to other series. Mid-abdominal colicky pain representing intermittent small bowel obstruction was seen in $83.52 \%$; it was seen in more than $90 \%$ patients in other series ${ }^{(18)}$. Fever was the second most common symptom; Muneef et al. reported fever as a major complaint ${ }^{(19)}$. Weight loss in $80 \%$ was higher than previously reported $^{(20,21,22)}$. Ascites was present in $23(13.14 \%)$ patients. In a series of 60 patients published by Chow et al. the most common features were ascites (93 percent), abdominal pain ( 73 percent) and fever (58 percent) ${ }^{(23)}$. Diarrhea (10 patients) and bleeding per rectum (13 patients) were seen less often patients as compared to other studies ${ }^{(20-22)}$. Seven had family history and $13(7.39 \%)$ had concomitant pulmonary TB. Eleven $(6.25 \%)$ patients had past history of tuberculosis. Rajput MJ et al. and Arif AU et al. have observed pre-existing pulmonary tuberculosis in $33.95 \%$ and $20 \%$ of their patients respectively ${ }^{(17,23)}$.

Pallor was present in $98(53.4 \%)$ patients with mean hemoglobin level of $8.3+/-2.1 \mathrm{gm} / \mathrm{L}$. Raised ESR and mild anemia in $50 \%$ to $80 \%$ patients were reported by Kapoor et al. ${ }^{(14)}$. Hepatomegaly was present in 13 patients and splenomegaly in three. Terminal ileum, IC valve and caecum were involved in $75(46 \%)$ patients on colonoscopy followed by terminal ileum alone in 32 . Only caecum was involved in eight patients. Large bowel other than caecum was involved in 14 patients. Both small and large bowel were involved in 13 patients. Four patients had associated gastroduodenal tuberculosis and one patient also had associated esophageal ulcera- 
tion. Patient with gastroduodenal tuberculosis had ulceronodular disease and fistulous opening in duodenum was seen two patients. One patient had growth in cardia of stomach mimicking malignancy with low SAAG (serum ascites albumin gradient). Overall ulceronodular lesions were most common followed by ulcerative or nodular lesion. Most of the ulcers were transverse ranging in size from 0.5 to $1.5 \mathrm{~cm}$ with an erythematous base; nodule with ulceration varying from 0.3 to $0.8 \mathrm{~mm}$ were seen, consistent with previous studies $^{(7,24-26)}$. Mukawar et al. had reported similar lesions on colonoscopy with predominantly right sided involvement ${ }^{(20)}$. In our study, strictures at different levels in bowel were seen in $28(15.9 \%)$ patients. Nagi et al. reported transverse colon as the most common site and strictures the most common lesion on CT abdomen $^{(27)}$. Most common site for stricture in our study was IC valve and terminal ileum followed by ascending colon, transverse colon and hepatic flexure. Kedia et al. reported 74 strictures in 106 patients; 52 (49.1\%) in distal ileum/ileocecal area, 37 (34.9\%) in colon, $4(3.8 \%)$ in ileum and colon, $10(9.4 \%)$ in proximal small bowel and $4(3.8 \%)$ in gastroduodenal area. After treatment in this study stricture healing was seen in $25(23.6 \%)$ patients, surgery required for seven patients and endoscopic dilatation required for 12 patients. Most of the strictures in our study had partial resolution on repeat colonoscopy at the end of treatment. Symptomatic improvement was seen in majority of them and only handful of patients required endoscopic and surgical interventions for stricture. This suggests that effective and timely ATT can resolve the inflammatory and edematous component of stricture thereby providing adequate symptomatic relief. In spite of endoscopic evidence of narrowing majority of them were asymptomatic suggesting that a conservative follow up strategy is best in these circumstances. Gain in weight and relief of symptoms were considered as markers for response to treatment.

Biopsies showed granuloma in $136(83.92 \%)$ patients predominantly consisting of epitheloid macrophages and langerhans giant cell (FIGURE 1). Caseating granulomas were found only in 34 $(25 \%)$ patients. All four patients with gastroduodenal tuberculosis showed epitheloid granuloma and/ langerhans giant cell. Alvares et al. demonstrated well-formed granulomas in 23 patients $(54 \%)$; $14(61 \%)$ of these patients had caseation ${ }^{(24)}$. In our study granuloma detection in biopsy specimen was very high but detection of caseous necrosis in granuloma was very low. Acid fast bacilli were seen only in $6(3.7 \%)$ patients which was also a rare finding in previous studies. Out of 23 patients with ascites ascitic fluid ADA ranged from 5 to 76 with mean values of $46+/-10 \mathrm{IU} / \mathrm{mL}$. Gupta et al. from India demonstrated that an ascitic fluid ADA level of 30 units/L had a sensitivity of $100 \%$ and specificity of $94.1 \%$ for tubercular peritonitis ${ }^{(27)}$.

Newer molecular methods like MGIT (mycobacterium growth indicator tube) and GeneXpert were positive in 43/132 (32.5\%) and $35 / 132(26.5 \%)$ patients respectively and 4 patients had both tests positive. The rate of culture positivity was higher in Shah et al's study where $76 \%$ of TB patients showed positive BACTEC 460TB cultures $^{(28)}$. This difference may be because while all cultures were established in our study using colonoscopic biopsies, Shah et al's samples were drawn from a range of procedures including colonoscopic, laparoscopic, and open surgical biopsies. Data on drug resistance from India in patients with abdominal tuberculosis is very scarce (TABLE 5). Samant et al. from Mumbai, India found that 30/61 (49\%) patients with primary abdominal TB had culture positive and 8 patients had drug resistance ${ }^{(29)}$. In our 43 patients
TABLE 5. Prevalence of drug resistance in different studies.

\begin{tabular}{lcccc}
\hline & $\begin{array}{c}\text { Samant } \\
\text { et al. }\end{array}$ & $\begin{array}{c}\text { Sonambekar } \\
\text { et al. }\end{array}$ & $\begin{array}{c}\text { Yan } \\
\text { et al. }\end{array}$ & $\begin{array}{c}\text { Current } \\
\text { study }\end{array}$ \\
\hline Sample size & 12 & 43 & 74 & 176 \\
Pan susceptible & 6 & 33 & 59 & 20 \\
Mono resistance & 3 & 4 & 13 & 3 \\
MDR & 3 & 6 & 2 & 8 \\
XDR & 0 & 0 & 0 & 0 \\
& & & & \\
\end{tabular}

with positive culture we did culture sensitivity for 26; 20 were drug sensitive, two had INH and Rifampicin resistance, one had INH, streptomycin, rifamipicin and olfoxacin resistance, two had only rifampicin resistance and one patient had isolated isoniazid resistance. GeneXpert was positive in 35 cases and out of these four were rifamipcin resistant in which MGIT was negative. Out of four patients who were both positive, three were rifampicin sensitive and one had rifampicin resistance. In a series of 30 patients with colonic TB in Taiwan, four $(13 \%)$ had MDR-TB ${ }^{(30)}$. Patients with rifampcin resistance on GeneXpert or MGIT were also considered to have MDR and were given CAT IV antitubercular drugs. Other patient in whom MGIT was negative antitubercular drugs given either on histological evidence of caseating granuloma and imaging evidence or response to treatment with two months of antitubercular drugs. Fifteen patients were given empirical antitubercular drugs based on clinical suspicion. Three patients died among them one due to intestinal obstruction and another two due to meningeal tuberculosis. All the other patients completed 9 months of CAT I (2HRZE/7HR) antitubercular drugs and 18 months for MDR tuberculosis.

In conclusion, our study shows that abdominal tuberculosis is still a diagnostic dilemma with varied modes of presentation. With the help of colonoscopy and biopsy and newer molecular methods, early treatment can be initiated and patients can be managed conservatively even with sub acute intestinal obstruction. Weight gain and resolving symptoms were considered early markers of treatment response. Patients with stricture on CT colonoscopy can become asymptomatic with treatment.

\section{Authors' contribution}

Udgirkar S: study concept and design, drafting the manuscript and critical revision of the manuscript for important intellectual content. Jain S and Pawar S: critical revision of the manuscript for important intellectual content. Chandnani S, Contractor Q, Rathi P: critical revision of the manuscript for important intellectual content.

\section{ORCID}

Suhas Udgirkar. Orcid: 0000-0002-1275-4833.

Samit Jain. Orcid: 0000-0002-8097-5291.

Sunil Pawar. Orcid: 0000-0003-0498-7079.

Sanjay Chandnani. Orcid: 0000-0001-8270-7680.

Qais Contractor. Orcid: 0000-0001-7191-8589.

Pravin Rathi. Orcid: 0000-0002-1095-3652. 
Udgirkar S, Jain S, Pawar S, Chandnani S, Contractor Q, Rathi P. Perfil clínico, teste padrão da resistência à droga e resultados do tratamento de pacientes com tuberculose abdominal da Índia ocidental. Arq Gastroenterol. 2019;56(2):178-83.

RESUMO - Contexto - A tuberculose abdominal é um problema crescente no mundo em desenvolvimento. Objetivo - O objetivo do estudo foi descrever as apresentações clínicas, o padrão de resistência a fármacos e os desfechos de tratamento da tuberculose abdominal na Índia ocidental. Métodos Foram incluídos todos os casos de tuberculose abdominal de maio de 2014 a abril de 2017, diagnosticados com base no perfil clínico e nos resultados morfológicos brutos na endoscopia, imagem latente, seguido pela histologia e/ou pela cultura de GeneXpert e de MGIT. Todos os pacientes receberam a terapia antitubercular da droga (AKT) de acordo com o protocolo nacional. Os pacientes foram acompanhados de diagnósticos até a conclusão do tratamento e vários parâmetros foram estudados. Resultados - Dos 176 pacientes, $48 \%$ eram do sexo masculino. A dor abdominal foi a queixa mais comum em $83,5 \%$. Na colonoscopia, o íleo terminal e a válvula íleo-cecal foram os segmentos mais comumente envolvidos. O trato gastrointestinal superior foi envolvido em quatro pacientes. As lesões ulceronodulares totais foram as mais comuns seguidas pela lesão ulcerosa/nodular. As estenoses foram observadas em 28 (15,9\%) pacientes priciplamente com a válvula íleo-cecal envolvida, dos quais 23 tiveram alívio sintomático com AKT e somente três necessitaram de dilatação. A histopatologia mostrou o granuloma em 80,8\% casos. O MGIT foi positivo em 43 ( $35,80 \%$ e GeneXpert foi positivo em 35 (26,1\%) casos. Oito pacientes tiveram tuberculose resistente a múltiplas drogas. Apenas dois pacientes necessitaram de manejo cirúrgico. Conclusão - A tuberculose abdominal com amplo espectro de apresentação, ainda pode ser manuseada com diagnóstico precoce e tratamento mesmo em pacientes com obstrução intestinal sub-aguda. Ganho de peso ou sintomas resolvidos foram considerados marcadores precoces de resposta ao tratamento. Pacientes com estenose podem se tornar assintomáticos com tratamento médico isoladamente.

DESCRITORES - Tuberculose. Abdome. Resistência a medicamentos. Constrição patológica. Granuloma.

\section{REFERENCES}

1. Tuberculosis Control In The South East Asia Annual Report 2016. Available from: http://www.searo.who.int/tb/ annual-tb-report-2016.

2. Kapoor VK. Abdominal tuberculosis. Post grad Med J. 1998;74:459-67.

3. Horvath KD, Whelan RL. Intestinal tuberculosis: return of an old disease. Am J Gastroenterol. 1998;93:692-6.

4. Wang HS, Chen WS, Su WJ, Lin JK, Lin TC, Jiang JK. The changing pattern of intestinal tuberculosis: 30 years' experience. Int J Tuber Lung Dis. 1998;2:569-74.

5. Misra SP, Misra V, Dwivedi M, Gupta SC. Colonic tuberculosis: clinical features, endoscopic appearance and management. J Gastroenterol Hepatol. 1999;14:723-9.

6. Aston NO. Abdominal tuberculosis. World J Surg. 1997;21:492-9.

7. Singhal A, Gulati A, Frizell R, Manning AP. Abdominal tuberculosis in Bradford, UK: 1992-2002. Eur J Gastroenterol Hepatol. 2005;17:967-71.

8. Hulnick DH, Megibow AJ, Naidich DP, Hilton Z, Cho KC, Balthazar EJ. Abdominal tuberculosis: CT evaluation. Radiology. 1985;157:199-204.

9. Vij JC, Malhotra V, Choudhary V, Jain NK, Prasaed G, Choudhary A, et al. A clinicopathological study of abdominal tuberculosis. Indian J Tuberc. 1992;39:213-20.

10. Shaikh MS, Dholia KR, Jalbani MA: Prevalence of intestinal tuberculosis in cases of acute abdomen. Pakistan J Surg. 2007;23:52-6.

11. Engin G, Balk E. Imaging findings of intestinal tuberculosis. J Comput Assist Tomogr. 2005;29:37-4.

12. Yunaev M, Ling A, Abbas S, Suen M, Pleass H. Abdominal tuberculosis: an easily forgotten diagnosis. ANZ J Surg. 2011;81:559-60.

13. Chaudhuri AD. Recent changes in technical and operational guidelines for tuberculosis control programme in India-2016: A paradigm shift in tuberculosis control. J Assoc Chest Physicians. 2017;5:1-9.

14. Kapoor VK. Abdominal tuberculosis: the Indian contribution. Indian J Gastroenterol. 1998;17:141-7.

15. Bolukbas C, Bolukbas FF, Kendir T, Dalay RA, Akbayir N, Sokmen MH, et al. Clinical presentation of abdominal tuberculosis in HIV seronegative adults. BMC Gastroenterology. 2005;5:21.

16. Chalya PL, Mchembe MD, Mshana SE, Rambau PF, Jaka H, Mabula JB. Clinicopathological profile and surgical treatment of abdominal tuberculosis: a single centre experience in Northwestern Tanzania. BMC Infect Dis. 2013;13:270

17. Rajpoot MJ, Memon AS, Rani S, Memon AH. Clinicopathological profile and surgical management outcomes in patients suffering from intestinal tuberculosis. J Liaqaut Uni Med Health Sci. 2005;4:113-8.
18. Khan SM, Khan KM, Khan AS, Jehanzeb M, Jan WA, Khan M, Ali U: Presentation of abdominal tuberculosis in NWFP and its correlation with operative findings. J Postgrad Med Inst. 2005;19:286-91.

19. Muneef MA, Memish Z, Mahmoud SA, Sadoon SA, Bannatyne R, Khan Y. Tuberculosis in the belly: a review of forty-six cases involving the gastrointestinal tract and peritoneum. Scand J Gastroenterol. 2001;36:528-32.

20. Mukewar S, Mukewar S, Ravi R, Prasad A, Dua KS. Colon tuberculosis: endoscopic features and prospective endoscopic follow-up after anti-tuberculosis treatment. Clinical and translational gastroenterology. 2012;3:e24.

21. Makharia GK, Srivastava S, Das P, Goswami P, Singh U, Tripathi M, et al. Clinical, endoscopic, and histological differentiations between Crohn's disease and intestinal tuberculosis. Am J Gastroenterol. 2010;105:642-51.

22. Khan R, Abid S, Jafri W, Abbas Z, Hameed K, Ahmad Z. Diagnostic dilemma of abdominal tuberculosis in non-HIV patients: an ongoing challenge for physicians. World J Gastroenterol. 2006;12:6371-5.

23. Arif AU, Shah LA, Ullah A, Sadiq MuD. The frequency and management of intestinal tuberculosis; a hospital based study. J Postgrad Med Instit. 2008;22.

24. Alvares JF, Devarbhavi H, Makhija P, Rao S, Kottoor R. Clinical, colonoscopic, and histological profle of colonic tuberculosis in a tertiary hospital. Endoscopy. 2005;37:351-6.

25. Singh V, Kumar P, Kamal J, Prakash V, Vaiphei K, Singh K. Clinicocolonoscopic profile of colonic tuberculosis. Am J Gastroenterol. 1996;91:565-8.

26. Das HS, Rathi P, Sawant P, Chodankar CM, Vyas K, Patrawala V, Dhadphale S. Colonic tuberculosis: colonoscopic appearance and clinico-pathologic analysis. J Assoc Physicians India. 2000;48:708-10.

27. Nagi B, Kochhar R, Bhasin DK, Singh K. Colorectal tuberculosis. Eur Radiol. 2003;13:1907-12.

28. Shah SR, Shenai S, Desai DC, Joshi A, Abraham P, Rodrigues C. Comparison of Mycobacterium tuberculosis culture using liquid culture medium and Lowenstein Jensen medium in abdominal tuberculosis. Indian J Gastroenterol. 2010;29:237-9.

29. Samant H, Desai D, Abraham P, Joshi A, Gupta T, Rodrigues C, George S. Acid-fast bacilli culture positivity and drug resistance in abdominal tuberculosis in Mumbai, India. Indian J Gastroenterol. 2014;33:414-9.

30. Lin PY, Wang JY, Hsueh PR, Lee LN, Hsiao CH, Yu CJ, Yang PC. Lower gastrointestinal tract tuberculosis: an important but neglected disease. Int J Colorectal Dis. 2009;24:1175-80. 